\title{
Relationship Between Awareness, Knowledge, and Attitude of Behavioural Intention Towards Halal Jobs among Malaysian Muslim University Students
}

\author{
Noor Haslihsa Hashim ${ }^{1}$, Nitty Hirawaty Kamarulzaman ${ }^{1,2 *}$, Suhaimi Ab Rahman ${ }^{1,3}$ and Mohhidin Othman ${ }^{1,4}$ \\ ${ }^{1}$ Halal Products Research Institute, Universiti Putra Malaysia, 43400 UPM Serdang, Selangor, Malaysia \\ ${ }^{2}$ Department of Agribusiness and Bioresource Economics, Faculty of Agriculture, Universiti Putra Malaysia, \\ 43400 UPM Serdang, Selangor, Malaysia
}

${ }^{3}$ Department of Management and Marketing, Faculty of Economics and Management, Universiti Putra Malaysia, 43400 UPM Serdang, Selangor, Malaysia

${ }^{4}$ Department of Food Management and Service, Faculty of Food Science and Technology, Universiti Putra Malaysia, 43400 UPM Serdang, Selangor, Malaysia

*Corresponding author: Nitty Hirawaty Kamarulzaman, ${ }^{1}$ Halal Products Research Institute, Universiti Putra Malaysia, 43400 UPM Serdang, Selangor, Malaysia; nitty@upm.edu.my

\begin{abstract}
In the emergence of the global halal market, developing halal human capital with provisions of knowledge and skills is indispensable for professional efficiency in management and implementation, especially for Malaysia as the world's leader in the halal industry. Therefore, it is important to determine the awareness among Muslim university students on job opportunities and their intentions to choose career paths in the halal industry. The objectives of this study were to determine the level of Muslim university students' awareness, knowledge and attitude towards halal jobs as well as to determine the relationship between awareness, knowledge and attitude of behavioural intention towards halal jobs. A structured questionnaire was used as a research instrument to collect responses from 1,454 final year Muslim university students in public and private universities located in Klang Valley, Malaysia. Data were analysed using descriptive analysis and Pearson correlation methods. Results of the study revealed that the Muslim university students have a high level of awareness, an adequate level of knowledge and an adequate level of attitude towards halal jobs. Besides, there was a moderate relationship observed between awareness and attitudes among Muslim university students. The present study concluded that positive awareness, knowledge, and attitude towards halal jobs influenced significantly on the respondents' behavioural intention towards their halal job preference. This study contributes to the growth and development of halal industries and halal jobs for the Muslims community to explore and reduce unemployment among Muslims with satisfactory human resources management practiced by the employers.
\end{abstract}

Keywords: awareness; knowledge; attitude; Muslim university students; halal jobs

Received: $18^{\text {th }}$ March 2020

Citation: Hashim NH, Kamarulzaman NH,

Accepted: $2^{\text {nd }}$ October 2020 Rahman SA, et al. Relationship between awareness, knowledge, and attitude of behaviourial intention towards halal jobs among Malaysian Muslim university students. J Halal Ind Serv 2020; 3(1):

Available Online: $22^{\text {nd }}$ October 2020 a0000152. https://doi.org/10.36877/jhis.a0000152 


\section{Introduction}

Halal and haram are the rules and spines in Muslims' daily lives in accordance with Islamic Shariah. The term halal covers a broad scope from food and beverage consumptions, human relations, business, trade, finance, to every aspect of behaviours (Samori et al., 2014). According to Al-Qaradhawi (2014), Al-Halal (the lawful), which is permitted, with respect to which no restriction exists, and the doing of which the lawgiver, Allah, has allowed. Hence, halal means whatever is allowed and wholesome for humanity, while haram means whatever is forbidden, and harmful (Maqsood, 1998). The word halal means what is acceptable by Islam and what is not acceptable by Islam (Hashim \& Mat Hashim, 2013). In contrast, 'haram' or 'haraam', in Arabic words strictly means illegal, prohibited, forbidden or illicit, interdicted, illegal, or banned and they are regarded as najis (unclean) from the perspective of Islamic law (Shariah). Thus, halal and haram are entailing with food and drink, behaviours and manners, styles and fashions, careers, or jobs to cover the daily lifestyle. Shariah is an integral part of Islam and the practical guidance for Muslims' lifestyle also connotes 'Islamic Laws'. Shariah from utterance 'Syara', which is explained and demonstrated by Islamic pledge, means to accept something legitimate. Shariah is also the law or the rules governing the relationship between all mankind. Every aspect of Muslims' life is regulated by Islamic Law (Shariah). The Shariah Law is based on the al-Quran (i.e. the Holy Book of Islam), Hadith and Sunnah, (i.e. habits and approvals of Prophet Muhammad (PBUH)), Ijma' (i.e. consensus of Ulama's), and Qiyas (i.e. deduction or analogy) according to various Islamic School of Thoughts (Mazhab) or fatwa approved by the relevant Islamic Authorities (Che Man \& Abdul Latif, 2002; Alanazi et al., 2018).

Malaysia has continued to flourish in the halal industry (MITI, 2016). In 2017, Malaysia recorded RM 43.3 billion in halal exports which made up RM 935.4 billion (4.6\%) of the nation's total exports. Among the top importers of halal products from Malaysia were China (RM4.9 billion), Singapore (RM 4.9 billion), Japan (RM 2.8 billion), the United States of America (USA) (RM 2.7 billion), and Indonesia (RM 2.2 billion) (MIHAS, 2019). Malaysia External Trade Development Corporation (MATRADE) was expected a 5\% increase in 2019 for the export value of halal products and services in fulfilling the significant global demand (MIHAS, 2019). According to the Department of Standards Malaysia (2017), there are a total of 568,481 small and medium enterprises (SMEs) in Malaysia, in which 347 SMEs are certified with Hazard Analysis and Critical Control Points (HACCP), 133 accredited with ISO22000, while 7,217 are certified with ISO9001 (Chik et al., 2018). Based on the numbers, 5,500 of the SMEs are halal-certified companies (SME Corporation Malaysia, 2016; Arsat, 2016; Chik et al., 2018). Halal Industry Master Plan (HIMP) (20082020) highlighted three main key performance indicators (KPIs) of halal: (1) to achieve halal export revenue amounting to RM 19 billion; (2) to create additional employment in the halal industry to 300,000 employments in 2020; (3) to achieve positive annual growth rate compared to 2010 (Halal Statistics, 2015). Halal RM 10.2 billion worth of incomes were recorded in 2015 compared to RM4.8 billion in 2010 with an average annual growth of $16.3 \%$. 
The halal industry sector is one of the major contributors to Malaysia's future economic growth. It is considered as one of the most important trading halal products or services in all of the economies and sectors that have generated many job opportunities. However, the halal industry depends on the quality and skills of human capital in ensuring the halal industry a success (MOHR, 2009). According to the Halal Industry Development Corporation (HDC), the job domains in the halal industry cover five sub-sectors following Malaysia Standard Industrial Classification (MSIC), which are comprised of Halal Logistics, Livestock Production, Food Manufacturing, Meat Processing, and Industry Management Services (HDC, 2018). There are 12 job areas in the halal industry such as halal compliance, purchasing, production, quality assurance, research and development, slaughtering operation, warehouse, transportation, livestock farming, livestock breeding, and livestock product (HDC, 2018). There are also 52 job titles in the halal industry with 18 job titles that have been identified as critical under five sub-sectors. All job titles are registered under the Malaysia Standard Classification of Occupations (MASCO). In 2017, HDC established 'Halal Talent Portal' as a platform that provides information on halal talents and employment availability, both domestically and globally. The platform also serves as a job portal with vast options and opportunities. It is also a channel that ensures industry flow with the network connection of qualified advisors and experts such as halal auditor, analyst, tourist guide, executive, trainer, Syariah advisor, marketing, chef, and health and personal care (HDC, 2017). In 2018, the 'Halal Talent Portal' registered a total of 1,997 talents and 55 companies as employers with 171 facilitations (HDC, 2018).

Halal human capital development requires intensive collaborative inputs, thoughts, and expertise from halal industry such as halal-certified companies, logistics, and supply chain organizations, authorities, and institutions of learning and training (Shariff et al., 2016). Halal human capital development consists of four main elements, namely knowledge, skills, abilities, and Shariah (Shariff et al., 2016). Halal human capital with provisions of knowledge and skills for professional efficiency in management and implementation is crucial in Malaysia (Muhammad et al., 2009; Shariff et al., 2016). It is also an important asset that determines the success of operational performance particularly in protecting the integrity of halal products (Gurcharan \& Mohamad, 2016). The costs of training local talents are the main issue resulting in a shortage of talents (HDC, 2016). Lack of halal-based orientation workers is identified as one of the challenges faced in the halal industry (MOHR, 2009).

The need for halal talented workers is highlighted as a priority, parallel with the improvement of the industry playmakers in the halal industry. According to Alina et al. (2013), the major challenges faced by the halal industry in Malaysia are the shortage of skilled workers and semi-skilled workers that understand the Shariah requirements and implementing Shariah knowledge into actual industrial practice to maintain the halal integrity. Hence, having these skilled and knowledgeable workers are critical to ensure the sustainable growth of the halal industry. Furthermore, the increasing demands of halal human capital such as halal executives, auditors, and committee members are driving the increasing number of halal training services (Shariff et al., 2016). Higher education institutions must 
bear the responsibility to provide an adequate workforce for the halal industry. Therefore, halal awareness, knowledge, and skills should be deliberately emphasized academically in higher learning institutions in universities and colleges to ensure the efficiency of halal skilled workers are created to produce halal products and services (Ahmad et al., 2011).

Since the introduction of Malaysian Halal Certification, the need for halal professionals has increased significantly which leads to the demand for competent halal executives and committee members (Jais, 2014; Che Hashim \& Mohd Shariff, 2016). In 2015, the Department of Islamic Development Malaysia (JAKIM) has reiterated the requirement for at least two Muslim skilled workers with permanent posts, full-time workers, and Malaysian citizens in the food handling or processing section. The appointment of halal executives is also required for halal certification. It is likely that lack of awareness, knowledge, or encouragement and reassurance among companies on halal certification that limit the halal talent availability and career options to university students. Thus, the awareness, knowledge, participation, and exposure for university students are crucial in producing skilled workers in the halal industry.

Nevertheless, studies on halal talents in relevant industries are still lacking and previous studies have only emphasized on halal food (Awan et al., 2015; Bashir et al., 2018; Yunus et al., 2018), cosmetics (Abd Rahman et al., 2014; Majid et al., 2015), and training and education (Jais, 2014; Rafida et al., 2013; Shariff et al., 2016; Ahmad et al., 2011). Furthermore, there is a lack of emphasis on measuring awareness, knowledge, and attitude among Malaysian students towards halal jobs. Consequently, the major challenge for government and the halal industry playmakers in developing talents from Muslim university students is to harness the capabilities and knowledge that they naturally embodied for halal jobs.

The influence of initiatives towards halal jobs among Muslim university students is yet to be evaluated. Moreover, research on halal jobs is important in understanding the awareness, knowledge, and attitude of behavioural intention towards halal jobs, as it also reflects the effectiveness of government initiatives in this aspect. Analysis of feedback from future potential workers could also improve the initiatives from the Malaysian government in strengthening halal talent workers. This could provide further support for future planning in promoting halal talent workers in Malaysia. The determinants of Muslim university students' behavioural intention towards halal jobs could provide students with their knowledge, understanding, and benefits. Therefore, the objectives of this study were: (i) to determine the level of Muslim university students' awareness, knowledge, and attitude towards halal jobs; (ii) to determine the relationship between awareness, knowledge, and attitude of behavioural intention towards halal jobs.

\section{Literature Review}

In accordance to the fundamentals of halal work or jobs, Islam has prohibited certain professions to all Muslims involving harmful and destructive acts, which are against the 
beliefs, morals, honour, and well-being of the society and surroundings such as manufacturing intoxicants and drugs, prostitution, dancing or erotic arts, involving usury (Riba'), making statues and similar activities. In short, any work or business that yields no benefit or harmful is prohibited. On the contrary, any job or business that is fair, beneficial to others, and obeys the rights of Islamic justice and wisdom is permissible. Any forms of earning money that involves dishonesty, cheating, deceit or fraudulent, bribery, robbery or burglary, hoarding in a negative way, exploitation, artificial surgery due of dissatisfaction of God's creation, anything to do with alcohol, gambling or lotteries, sexual degradation or any immoral practices or any other means of making profit by exploiting others is forbidden to the Muslim (Maqsood, 1998). The aforementioned profession or job is strictly prohibited in Islam as it may affect and even harm the society in terms of faith, morale, self-esteem, honour, and courtesy (Shahid, 2017). Thus, all jobs and businesses which are permissible, halal, should not involve any prohibited acts (i.e. haram) in Islam. The great scholars and jurists have postulated the term obligations as "the obligations of sufficiency" (fardu kifayah), where Muslim community must engage in every essential science, industry, and profession to meet its needs (Shahid, 2017). Imam al-Ghazali justified fardu kifayah as all knowledge that is essential to the world, such as doctoral science, as it is necessary to maintain the health of the body. In addition, mathematics for daily businesses and the division of legacies and inheritance and what not also uses the practice of "the obligations of sufficiency".

Awareness is the ability to perceive, to feel, to be conscious, and to imply understanding and perception towards specific situations (Aziz \& Chok, 2013). According to Merikle (1984), awareness equates with the ability to make a forced-choice decision above the chance level of performance. Awareness is subjective and simply equates awareness with self-reports indicating that an observer "consciously sees" a stimulus (Henley, 1984). Further, according to Nguyen and Watanabe (2019), awareness pertains to an observer's consciousness and ability to discriminate among several possible stimulus states. Besides, awareness can be described as a level of attentiveness or realization among Muslim entrepreneurs towards halal production (Ambali \& Bakar, 2014). Awareness comprises education and skill requirements, types of job availabilities, regulations, and expectations of industry (Nasir \& Lin, 2013). Every Muslim has a different level of awareness depending on their religious belief, halal exposure, logo, and health reason in terms of Muslim awareness towards halal consumptions (Ambali \& Bakar, 2014). Aminrad et al. (2013) revealed an insignificant relationship between awareness and attitude among students. Furthermore, Salman and Siddiqui (2011) stated that religious people may not necessarily have a high level of awareness. Awareness factors among Malaysians have been acknowledged to be increasing, yet their level of awareness is still low compared to other countries such as Indonesia and Thailand (Yusoff \& Adzharuddin, 2017). A study conducted by Rafida et al. (2013) revealed that there is a moderate and positive relationship between consumers' awareness of halal goods and certification. It implies the increment of level in awareness towards halal issues is correlating with the increase of their perceptions towards halal certification. 
Awareness is significantly correlated with information-seeking behaviour among Muslims and information-seeking action is sparked by curiosity and awareness of the existence of the knowledge gaps. In addition, Muslim's awareness is a great power to educate the workers or halal human capital in producing halal market (Yusoff \& Adzharuddin, 2017). However, level of awareness among Muslim workers towards the granting of halal certification is very low (Tawil et al., 2015). Besides, there is also halal awareness initiated by certain bodies of authorities who provide training to increase the level of awareness on the principles and concepts of halal, educating the importance of proper sourcing of raw materials and production of halal food and consumer products and sharing the knowledge in halal industry. Training will ensure the realization in creating awareness and integrity of halal process (Che Hashim \& Shariff, 2016).

Knowledge is referred to as an understanding of a subject which is obtained through experience, while halal knowledge is how individuals or Muslims should digest and practice Islamic teachings regarding halal and haram (Sadeeqa et al., 2013). Knowledge is an important influence on halal purchase intention (Shaari \& Arifin, 2010). Lack of knowledge, awareness, and understanding on halal concept affected the loss of appreciation on halal among Muslims and product manufacturers (Wahab, 2004). Awareness, knowledge, and attitude towards food labels, subjective norm, and perceived behavioural control are factors that influence intention to purchase (Latiff et al., 2016). Said et al. (2014) revealed that there is a lack of initiative and disclosure of halal knowledge, information, and education from government agencies.

The awareness and knowledge among students on the halal concept are crucial in ensuring the continuity of halal education among university students (Elias et al., 2016). Muslim students demonstrate a positive relationship between awareness, knowledge, and intention towards producing halal products and possess a high level of halal awareness and knowledge to motivate them to become a Muslim entrepreneur. Meanwhile, the best predictor of consumer purchase intention towards halal food is their knowledge on halal processes such as slaughtering, storage, and packaging (Yusoff et al., 2015). Unfortunately, the familiarity concept of halal especially among Muslim students is inhibited by the extremely low level of awareness and knowledge towards halal certification and branding (Rajagopal et al., 2011). Abd Rahman et al. (2014) indicated that the relationship between Muslims' knowledge and attitude is insignificant towards halal cosmetic products. Meanwhile, according to Neni et al. (2019), the relationship between awareness, knowledge, and attitude correlates with attitude, moderate, awareness, and knowledge. Furthermore, Aminrad et al. (2013) revealed there is a significant and weak relationship between knowledge and awareness and insignificant relationship between attitude and knowledge among students. High level of awareness and adequate knowledge plus favourable attitude from students may have been influenced by the families, teachers, media, private reading and school curriculums (Aminrad et al., 2013). 
Attitude towards behaviour is an individual belief whether the person decides to or not to perform a certain behaviour that contributes either positively or negatively to a certain activity. Attitude is related to belief in terms of halal food (Salman \& Siddiqui, 2011). According to Ahmad and Omar (2016), religious belief, availability of halal label and exposure to halal concept demonstrate a significant positive effect on consumer attitude towards halal cosmetics. Attitude is found to be valid predictors of intent to purchase halal personal care products in Pakistan (Ansari \& Mohammed, 2015). The authors also found that there is a significant and positive relationship between attitude and behavioural intention of purchasing halal cosmetics products. Abd Rahman et al. (2014) revealed there is a significant positive relationship between attitude and religiosity and between attitude and intention towards halal cosmetics products. This is supported by Zakaria (2017), who demonstrated that religiousity is the most influential factor towards intention to purchase halal products. On the contrary, Kusumawardhini et al. (2016) stated that the effect of religiousity on intention towards Islamic brand is not significant. In another study by Elseidi (2018) revealed that attitude was used as a variable to predict the behaviour of Muslim consumers where high and low Islamic religiosity influenced the intention to purchase halal food products. Ishak et al. (2017) indeed showed that attitude is significant and the direct effect of intention towards halal food outlet. However, Marmaya et al. (2019) revealed that the attitude of Gen-Y consumers was not significant on the intention to purchase halal food. Earlier, Abd Aziz et al. (2017) revealed the factors that influence the public university graduates' career intention in the franchise industry are moderately high and attitude is significantly correlated with intention towards career intention.

Behavioural intention is referred to an individual's probability that he or she will perform the behaviour (Ajzen, 1991). According to Latiff et al. (2016), purchasing behavioural intention was influenced by awareness, knowledge, attitude, as well as food labels. Meanwhile, Yunus et al. (2014) described that behavioural intention was influenced by halal awareness towards purchasing halal products. Similarly, Aziz and Chok (2013) stated that purchase intention was influenced by awareness towards halal products. It is also revealed that attitude is positively related to behavioural intention to choose halal products (Lada et al., 2009). Furthermore, the behavioral intention to become halal entrepreneurs was influenced by awareness, knowledge, attitude, subjective norm, perceived behavioural control, and perceived relational support (Elias et al., 2016; Ambad et al., 2016; Mohammed et al., 2017).

\section{Methodology}

The conceptual framework (Figure 1) was established based on several studies (Ajzen, 2002; Aminrad et al., 2013; Latiff et al., 2016; Neni et al., 2019) to determine the relationship between awareness, knowledge, and attitude of Muslim university student's behavioural intention towards halal jobs. 


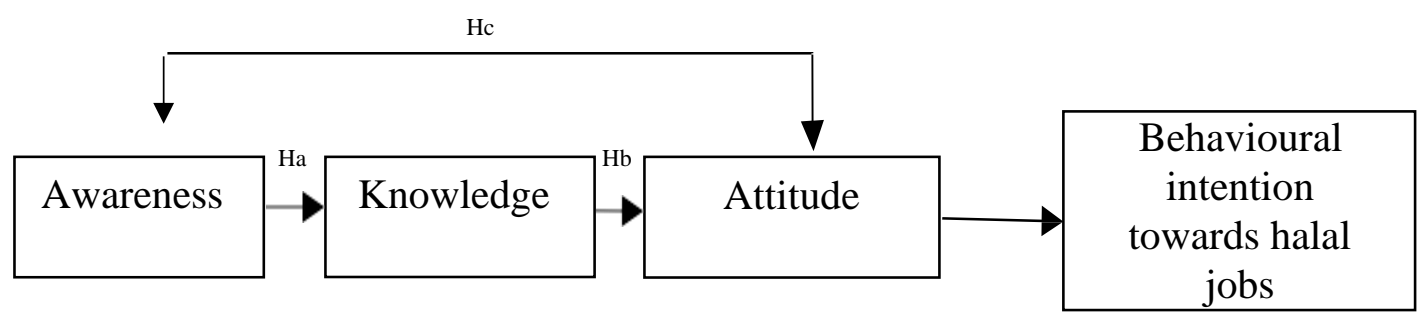

Figure 1. Conceptual framework. Adapted from Ajzen (2002); Aminrad et al. (2013); Latiff et al. (2016); Neni et al.(2019).

Several null and alternative hypotheses were established and tested in this study as the following:

$\mathrm{H}_{0}$ : There is no relationship between Muslim university students' awareness and knowledge towards halal jobs.

$\mathrm{H}_{\mathrm{a}}$ : There is a relationship between Muslim university students' awareness and knowledge towards halal jobs.

$\mathrm{H}_{0}$ : There is no relationship between Muslim university students' knowledge and attitude towards halal jobs.

$\mathrm{H}_{\mathrm{b}}$ : There is a relationship between Muslim university students' knowledge and attitude towards halal jobs.

$\mathrm{H}_{0}$ : There is no relationship between Muslim university students' awareness and attitude awareness towards halal jobs.

$\mathrm{H}_{\mathrm{c}}$ : There is a relationship between Muslim university students' awareness and attitude towards halal jobs.

A quantitative approach was used in this study to collect data from 1,454 Muslim university students using a self-administered questionnaire. A structured questionnaire was designed to cater the objectives of this study. Purposive sampling was conducted towards a selective, or subjective group of informants (Saabar \& Ibrahim, 2014) and used as the sampling method from selected public and private universities located in Klang Valley, Malaysia. The samples were selected based on the researcher's reliance on his/her judgement in choosing the populations that are suitable to provide the right information for the research (Kumar, 2011). The criteria of the respondents in this study were: 1) Muslims 2) university students, and 3) final year bachelor's degree students. Muslim university students were chosen because of the element of religious belief and also to focus on Shariah (Islamic law). The final year bachelor degree students were targeted because they will lead to specific professions immediately upon graduation (Amani et al., 2013).

The questionnaire was constructed in Malay language and consisted of four sections. A total of 10 statements using 3-Point Likert scales $(1=$ No, $2=$ Not Sure, $3=$ Yes $)$ related to respondents' awareness towards halal jobs were established (Yusof et al., 2014; Rafida et al., 2013). The use of 3-Point Likert scales for this section is to measure the degree level of respondents' awareness. A score of 1 was given to every "yes" answer whereas score of 0 was 
given to "no" and "not sure" answers. The "yes" answer means the respondents are aware towards halal jobs whereas "no" and "not sure" answers mean the respondents are not aware towards halal jobs. This score is used to recode the data for score analysis. Respondents' awareness was calculated based on a total score of awareness for each question and categorised as high and low levels. The overall score for awareness was from 0 to 10 and the cut-off point was determined at $50 \%$ of total range score (Darlington et al., 2019). Respondents with high level of awareness were scored from 6 to 10, while those with low level of awareness were scored 0 to 5. Scales of awareness level were adapted from Yusoff et al. (2017).

To determine respondents' knowledge towards halal jobs, 12 statements using 3-Point Likert scales ( 1 = No, 2 = Not Sure, 3 = Yes) were established (Akhtari-Zavare et al., 2016; Liu et al., 2016; Sadeeqa et al., 2013). The use of 3-Point Likert scales for this section is to measure the degree level of respondents' knowledge. A score of 1 was given to every "yes" answer whereas score 0 was given to "no" and "not sure" answers. The "yes" answer means the respondents have knowledge towards halal jobs whereas "no" and "not sure" answers mean the respondents have no knowledge towards halal jobs. The score was used to recode the data for score analysis. Respondents' knowledge was calculated based on a total score of knowledge for each question and categorised as adequate and inadequate levels (Al-lela et al., 2014; Mohd Azaman et al., 2016; Habte et al., 2018; Al-Qattan et al., 2019). The overall score for knowledge ranged 0 to 12 and the cut-off point was labelled at $50 \%$ range of total score (Darlington et al., 2019; Nwankwo et al., 2018; Ismail et al., 2018). Respondents with adequate knowledge were assigned to a score of 7 to 12 , while those with inadequate knowledge were assigned to a score of 0 to 6. Scales of knowledge level were adapted from Al-lela et al. (2014); Mohd Azaman et al. (2016); Habte et al., (2018); Al- Qattan et al. (2019).

There were 8 statements using 5-Point Likert scales $(1=$ Strongly Disagree, 2 = Disagree, 3 = Neutral, 4 = Agree, 5 = Strongly Agree) related to respondents' attitude towards halal jobs were established (Abdullahi et al., 2016). The attitude was calculated based on a mean score for each question and categorised as favourable and unfavourable levels (Mohd Azaman et al., 2016; Alnujaim et al., 2017; Habte et al., 2018). An overall score for attitude ranged between 17 to 85 and the cut of point was determined at $50 \%$ of range total score. Respondents who have a favourable level of attitude were scored 52 to 85, while those who have an unfavourable level of attitude were scored 17 to 51. Scales of attitude level were adapted from Ismail et al. (2018); Habte et al. (2018); Al-Qattan et al. (2019). Descriptive analysis was used to analyse the socio-demographic profiles of the university students and their behavioural intention towards halal jobs. The scores of awareness, knowledge, and attitude among Muslim university students were also calculated. Pearson correlation analysis was used to identify the relationship between awareness, knowledge, and attitude towards halal jobs. 


\section{Results and Discussions}

\section{Socio-Demographic Profiles}

Table 1 shows the socio-demographic profiles of the respondents. The total number of 1,454 respondents were comprised of $69.7 \%$ (1,014 respondents) female and $30.3 \%$ (440 respondents) male. The respondents with the age range of 20 to 24 years were the majority of respondents who participated in the study, accounted for $94.4 \%$ (1,372 respondents), and $5.2 \%$ (76 respondents) aged 25 to 29 . There were only $0.2 \%$ (4 respondents) aged 30 to 34 , while $0.1 \%$ ( 2 respondents) with the age of above 35 . In regard to ethnicity groups in this study, the respondents are comprised of $95.8 \%$ Malays (1,393 respondents), $1.4 \%$ Chinese (21 respondents), $0.6 \%$ Indians ( 8 respondents) and $2.2 \%$ other races (32 respondents).

Majority of the respondents $(99.4 \%, 1,445$ respondents) were single and only $0.6 \%$ (9 respondents were married. The majority of respondents $(56.5 \%, 821$ respondents) possessed working experience, whereas $43.5 \%$ (633 respondents) did not. A great number of students participated in the study $(83.6 \%, 1,215$ respondents) were funded by sponsorships such as Perbadanan Tabung Pendidikan Tinggi Nasional (PTPTN) Education Financing Scheme, Majlis Amanah Rakyat (MARA) Scholarship, Yayasan Selangor Scholarship, etc. and only $16.4 \%$ (239 respondents) were self-funded.

Table 1. Socio-demographic profiles of respondents.

\begin{tabular}{lll}
\hline Characteristics & Frequency $(\boldsymbol{n})$ & Percentage $(\%)$ \\
\hline Gender & & 69.7 \\
\hline Female & 1,014 & 30.3 \\
Male & 440 & \\
\hline Age (years) & 1,372 & 94.4 \\
\hline $20-24$ & 76 & 5.2 \\
$25-29$ & 4 & 0.2 \\
$30-34$ & 2 & 0.1 \\
Above 35 & & \\
\hline Race & 1,393 & 95.8 \\
\hline Malay & 21 & 1.4 \\
Chinese & 8 & 0.6 \\
Indian & 32 & 2.2 \\
Others & & \\
\hline Marital Status & & 99.4 \\
\hline Single & 1,445 & 0.6 \\
Married & 9 & 16.4 \\
\hline Financial Assistance & & 83.6 \\
\hline Self-Funded & 239 & \\
Sponsorship & 1,215 & 56.5 \\
\hline Working Experience & & 43.5 \\
\hline Yes & 821 & \\
No & 633 & \\
\hline
\end{tabular}




\begin{tabular}{lll}
\hline Characteristics & Frequency $(\boldsymbol{n})$ & Percentage (\%) \\
\hline University & & \\
\hline Universiti Putra Malaysia (UPM) & 280 & 19.3 \\
University Malaya (UM) & 159 & 10.9 \\
Universiti Kebangsaan Malaysia (UKM) & 119 & 8.2 \\
International Islamic University Malaysia (IIUM) & 117 & 8 \\
Universiti Teknologi MARA (UiTM) & 166 & 11.4 \\
Universiti Pertahanan Nasional Malaysia (UPNM) & 93 & 6.4 \\
Universiti Kuala Lumpur (UniKL) & 168 & 11.6 \\
Universiti Tenaga Nasional (UNITEN) & 114 & 7.8 \\
Management and Science University (MSU) & 125 & 8.6 \\
Universiti Selangor (UNISEL) & 113 & 7.8 \\
\hline Program & & 10.0 \\
\hline Islamic Studies & 146 & 5.2 \\
Education & 76 & 34.4 \\
Social Science, Business and Law & 501 & 30.2 \\
Science, Mathematic \& Computer & 439 & 11.1 \\
Engineering, Manufacturing \& Construction & 161 & 9.0 \\
Agriculture \& Veterinary & 131 & \\
\hline$n=1,454$ & &
\end{tabular}

The Higher Education Institute (HEI) involved in this study consisted of 6 public and 4 private universities in Klang Valley, Malaysia. Table 1 shows that students from Universiti Putra Malaysia (UPM) as the majority of the total respondents, accounted for $19.3 \%$ (280 respondents), whereas Universiti Pertahanan Negara Malaysia (UPNM) comprised as the minority, accounted for $6.4 \%$ (93 respondents). Participants from Universiti Malaya (UM) were accounted for $10.9 \%$ (159 respondents), Universiti Kebangsaan Malaysia (UKM) 8.2\% (119 respondents), International Islamic University Malaysia (IIUM) 8\% (117 respondents), Universiti Teknologi MARA (UiTM) 11.4\% (166 respondents), Universiti Kuala Lumpur (UniKL) 11.6\% (168 respondents), Universiti Tenaga Nasional (UNITEN) 7.8\% (114 respondents), Management and Science University (MSU) 8.6\% (125 respondents) and Universiti Selangor (UNISEL) accounted by $7.8 \%$ (113 respondents). The results also showed that the participants educated in the field of social science, business, and law recorded the highest number of respondents with $34.4 \%$ (501 respondents), followed by science, mathematics, and computer field with 30.2\% (439 respondents), engineering, manufacturing, and construction field $11.1 \%$ (161 respondents), Islamic studies 10.0\% (146 respondents), agriculture and veterinary $9.0 \%$ (131 respondents), while the least number of respondents $(5.2 \%, 76$ respondents) were educated in the education field.

\section{Awareness Level}

The level of awareness was calculated based on a total score for each respondent. From the awareness statements, 10 were related to respondents' awareness towards halal jobs. The items were evaluated using 3-point Likert scales ranging from 1 to 3 ( $1=$ No, $2=$ Not 
Sure, 3 = Yes) (Yusof et al., 2014; Rafida et al., 2013). A score of 1 was given to every "true" answer while score 0 was given to "false" and "not sure" answers. The overall score for awareness ranged from 0 to 10 and the cut-off point was determined at $50 \%$ range from the total score (Darlington et al., 2019; Ismail et al., 2018). The awareness level was categorized into two levels namely high awareness and low awareness. The score ranges between 6 to 10 was assigned to respondents with high level of awareness, whereas the score between 0 to 5 was assigned to those who have a low level of awareness. The scales of awareness level were adapted from Yusoff et al. (2017). Table 2 summarizes the awareness level towards halal jobs from the respondents. The results showed that $88.2 \%(n=1,284)$ of the respondents have high awareness, whereas $11.6 \%(n=170)$ have low awareness.

Table 2. Awareness Level.

\begin{tabular}{lccc}
\hline Awareness Level & Score & Frequency $(\boldsymbol{n})$ & Percentage (\%) \\
\hline High & $6-10$ & 1,284 & 88.2 \\
Low & $0-5$ & 170 & 11.6 \\
\hline Total & & $\mathbf{1 , 4 5 4}$ & $\mathbf{1 0 0}$ \\
\hline$n=1,454$ & &
\end{tabular}

\section{Knowledge Level}

Respondents' knowledge level was calculated based on a total score for each respondent and labelled as adequate and inadequate (Al-lela et al., 2014; Mohd Azaman et al., 2016). From the knowledge statements, 12 were related to respondents' knowledge towards halal jobs. The items were evaluated using Likert scales ranging from 1 to 3 ( $1=$ No, 2 = Not Sure, 3 = Yes) (Akhtari-Zavare et al., 2016; Liu et al., 2016; Sadeeqa et al., 2013). A score of 1 was given to every "true" answer, while score 0 was given to "false" and "not sure" answers. The overall score for knowledge ranged from 0 to 12 and the cut-off point was determined at 50\% range of total score (Darlington et al., 2019; Nwankwo et al., 2018; Ismail et al., 2018). Respondents who were labelled as adequate scored 7 to 12 , while those who were inadequate scored 0 to 6 . Scales of awareness level were adapted from Al-lela $e t$ al. (2014); Habte et al. (2018); Al-Qattan et al. (2019). Table 3 summarizes the knowledge level towards halal jobs from the respondents. The results showed that $91.7 \%(1,333)$ of the students have adequate knowledge, as opposed to 8.4\% (121) with inadequate knowledge. The finding was in line with Nuratifah et al. (2019) on the adequate level of knowledge towards halal jobs.

Table 3. Knowledge Level.

\begin{tabular}{lccc}
\hline Knowledge Level & Score & Frequency $(\boldsymbol{n})$ & Percentage $(\boldsymbol{\%})$ \\
\hline Adequate Knowledge & $7-12$ & 1,333 & 91.7 \\
Inadequate Knowledge & $0-6$ & 121 & 8.4 \\
\hline Total & & $\mathbf{1 , 4 5 4}$ & $\mathbf{1 0 0}$ \\
\hline$n=1,454$ & &
\end{tabular}




\section{Attitude Level}

Respondents' attitude level was calculated based on a mean score of attitudes for each question and categorised as favourable and unfavourable attitude. From the attitude statements, eight were related to respondents' attitude towards halal jobs. The items were evaluated using Likert scales ranging from 1 to 5 ( $1=$ Strongly Disagree, $2=$ Disagree, $3=$ Neutral, $4=$ Agree, $5=$ Strongly Agree) (Abdullahi et al., 2016). The overall score for attitude ranged from 17 to 85 and the cut-off point was determined at the range of 50\% from the total score (Darlington et al., 2019; Nwankwo et al., 2018). Respondents who have favourable attitude scored 52 to 85 , while those who have unfavourable attitude scored 17 to 51 . Table 4 summarizes the attitude level towards halal jobs from respondents. The result shows that 96.4\% ( $n=1,398)$ of the respondents possessed favourable attitude, as opposed to $3.9 \%$ ( $n=$ 56), who possessed unfavourable attitude.

Table 4. Attitude Level.

\begin{tabular}{lccc}
\hline Attitude Level & Score & Frequency $(\boldsymbol{n})$ & Percentage (\%) \\
\hline Favourable Attitude & $52-85$ & 1,398 & 96.4 \\
Unfavourable Attitude & $17-51$ & 56 & 3.9 \\
\hline$n=1,454$ & &
\end{tabular}

\section{Relationship between Awareness, Knowledge, and Attitude towards Behavioural Intention of Halal Jobs}

Pearson correlation analysis was used to measure the strengths and directions of the linear relationship between two variables. In this study, Pearson Correlation analysis was used to examine the strength of relationships between awareness, knowledge, and attitude towards behavioural intention of halal jobs.

Table 5 summarizes the Pearson correlations analysis. Firstly, the result showed there was a positive relationship at $1 \%$ level of significance between awareness and knowledge. The $\mathrm{H}_{0}$ hypothesis was rejected, indicating there was a significant relationship between Muslim university students' awareness and knowledge towards halal jobs. The strength of the relationship was moderate between awareness and knowledge with $r=0.411(p<0.000)$. Secondly, the result showed there was a positive relationship at $1 \%$ level of significance between knowledge and attitude. The $\mathrm{H}_{0}$ hypothesis was rejected, indicating a significant relationship between university students' knowledge and attitude towards halal jobs. The strength of relationship was weak between knowledge and attitude with $r=0.303(p<0.000)$. Lastly, the highest score showed there was a positive relationship at $1 \%$ level of significance between attitude and awareness. The $\mathrm{H}_{0}$ hypothesis was rejected, indicating a significant relationship between university students' attitude and awareness towards halal jobs. The strength of relationship was moderate between awareness and attitude with $r=0.416$ ( $p<$ 0.000). The present findings are in accordance with Aminrad et al. (2013) where the relationship between knowledge and awareness is significant, but weak. While the relationship between awareness and attitude is significant and have high relationship among 
students. Neni et al. (2019) revealed the significant but weak relationship between awareness and knowledge and attitude among students.

Table 5. Relationships between knowledge, awareness, and attitude of behavioural intention towards halal jobs.

\begin{tabular}{llcccc}
\hline Awareness & Awareness & Knowledge & Attitude & Decision \\
& $\begin{array}{l}\text { Correlation } \\
\text { Coefficient } \\
\text { Sig. (2-tailed) }\end{array}$ & 1 & $0.411^{* * *}$ & $0.416^{* * *}$ & Reject $\mathrm{H}_{\mathrm{o}}$ \\
\hline Knowledge & $\begin{array}{l}\text { Correlation } \\
\text { Coefficient } \\
\text { Sig. (2-tailed) }\end{array}$ & $0.411^{* * *}$ & 1 & 0.000 & \\
\hline Attitude & $\begin{array}{l}\text { Correlation } \\
\text { Coefficient }\end{array}$ & 0.000 & & $0.003^{* * *}$ & Reject $\mathrm{H}_{0}$ \\
& Sig. (2-tailed) & $0.416^{* * *}$ & $0.303^{* * *}$ & 1 & Reject $\mathrm{H}_{0}$ \\
& & 0.000 & 0.000 & & \\
\hline
\end{tabular}

Note: $n=1,454$

*** Correlation is significant at $1 \%$ level of significance (2-tailed)

$* *$ Correlation is significant at $5 \%$ level of significance (2-tailed)

* Correlation is significant at $10 \%$ level of significance (2-tailed)

\section{Limitations and Suggestions for Future Research}

This study had a few limitations that have been noted and need to be improved. Firstly, it is important to discuss the demographical background of the samples assessed, in which the gender of respondents were mostly female Muslim university students. This may result to gender biased finding. Hence, the sampling size and targeted group should be further stratified based on the number of total populations of male and female, so that the distribution of gender in all Universities listed will be well represented. Secondly, the study only focused on six public universities and four private universities due to the difference in their semesters' schedule, time constraint, and cost that lead to only four private universities in Klang Valley were chosen. The number of public and private universities to be chosen for this study should be based on fair percentages that will represent the whole Malaysia. Online survey technique may reduce the conflicts of timetable as an issue, as more Universities, both public and private universities can participate in the study. Thirdly, this study only focused on the final year bachelor students, which excluded those students who were undergoing internship training during this data collection. This can be prevented by reaching those who undergoes internship training through email or online survey after obtaining their contact through the respective faculties. Furthermore, the sampling should be conducted at all levels of programme offered from Diploma to Postgraduate level. Fourth limitation of this study is that it only assessed the students' behavioural intention to decide on their career choices. Intention can predict behaviour with a considerable degree of accuracy, this is often dependent on the behaviour being assessed (Fishbein \& Ajzen, 2010). Thus, in this study, the actual behaviour is not measured. This can be measured with face to face interview of selected respondents. Finally, another constraint of this is study was to get the accurate number of Muslim university populations in Klang Valley. This can be done by obtaining the secondary data from the Ministry of Higher Education of Malaysia which has categorized the Universities 
based on programmes offered. Hence, for the purpose of this study, we shall select those Universities that are Islamically oriented in terms of their courses offered and mode of delivery, teaching and training of students that promote halal concept and approach in all aspects. Comparisons can be further made between Islamically oriented Universities and conventional Universities to determine the impact of teaching and training mode (Islamic/Non-Islamic) practiced by the academic staff throughout the students' academic life. In future research, the actual behaviour should be measured through actual behavior or criteria to be met by fellow halal jobs' applicants, perhaps through the feedback given by fellow halal Industries' and Companies' Human Resources Department. The finding from this approach may resulted to the amendment of existing curriculum and module in the Malaysian Universities to inculcate the knowledge, skills and awareness necessary to become a successful halal job employee.

\section{Conclusion}

In general, this study indicates Muslim university students' knowledge, awareness, and attitude towards halal jobs among Muslim university students in the Klang Valley, Malaysia. The result revealed that most of the respondents have high level of awareness, adequate knowledge, and favourable attitude towards halal jobs. The Pearson correlation has proven that knowledge, awareness, and attitude have positive and significant relationships. Thus, the correlation value indicates that the more awareness and knowledge among the students on halal jobs, the higher the behavioural intention towards the option for halal jobs. This study has provided a significant impact on awareness, knowledge, and attitude of behavioural intention towards halal jobs among Muslim university students. There is a lack of emphasis especially in academic research and society on the determinants of awareness, knowledge, and attitude of behavioural intention towards halal jobs among Muslim university students. Various initiatives such as halal training and 'Halal Talent Portal' establishment have been carried out to increase participation and awareness towards career in halal industry. Therefore, the higher education institutions (HEI) should create strong opportunities and incentives such as study visits/benchmark to halal-certified factories or companies for future halal talent workers that can simultaneously introduce or expose students to the specific requirements for halal industry occupation. Such initiatives must be acted upon to enhance the effectiveness of the plan implemented by institutions of higher education to produce halal talent workers. The exposure, awareness, and knowledge towards halal jobs and halal industry should be continued and intensified not only focusing on higher education levels but the introduction of halal education should commence early at the school levels.

\section{Acknowledgments}

This work would not have been possible without the support of the Halal Products Research Institute (HPRI), Universiti Putra Malaysia. 


\section{Conflict of Interest}

The author declares no potential conflict of interest with respect to the research, authorship, and/or publication of this article.

\section{Reference}

Abd Aziz, N. A., Abd Aziz, N. A., Abd Aziz, N. N., et al. (2017). Factors influence intention to participate in franchise industry as a career option: a study on Malaysian public university graduates. Intercontinental Journal of Marketing Research Review, 5(8), 60-73.

Abd Rahman, A., Asrarhaghighi, E. \& Ab Rahman, S. (2014). Consumers and halal cosmetic products: knowledge, religiosity, attitude and intention. Journal of Islamic Marketing, 6(1), 148-163.

Abdullahi, A., Hassan, A., Kadarman, N., et al. (2016). Food safety knowledge, attitude, and practice toward compliance with abattoir laws among the abattoir workers in Malaysia. International Journal of General Medicine, 9(1), 79-87.

Ahmad, H., Fazullah, A., Abidin, A. Z., et al. (2011). Halal studies in universities: a way forward to manage halal business. International of Arts and Sciences, 4(9), 247-254.

Ahmad, S. N. B. \& Omar, A. (2016). Influence of attitude on consumers' behavioural intention toward halal cosmetic in Malaysia. Journal of Business Innovation, 1(1), 57-72.

Ajzen, I. (1991). The theory of planned behavior. Organizational Behavior and Human Decision Processes, 50(2), 179-211.

Ajzen, I. (2002). Perceived behavioral control, self-efficacy, locus of control, and the theory of planned behavior, Journal of Applied Social Psychology, 32(2), 665-683.

Akhtari-Zavare, M., Juni, M. H., Said, et al. (2016). Result of randomized control trial to increase breast health awareness among young females in Malaysia. BMC Public Health, 16(1), 738-742.

Alina, A. R., Rafida, A. N., Syamsul, H. K. M. W., et al. (2013). The academia's multidisciplinary approaches in providing education, scientific training and services to the Malaysian halal industry Middle-East. Journal of Scientific Research 13 Approaches of Halal and Thoyyib for Society, Wellness and Health, 79-84.

Al-lela, O. Q. B., Bahari, M. B., Salih, M. R., et al. (2014). Factors underlying inadequate parents' awareness regarding pediatrics immunization: findings of cross-sectional study in Mosul- Iraq. BMC Pediatrics, 14(1), 29-38.

Alnujaim, N. H., Albedaie, E. S., Alyahya, L. S., et al. (2017). Awareness, knowledge and attitudes of Saudi pregnant women towards cleft lip and palate. Current Pediatrics Research, 21(4), 596-603.

Al-Qaradawi, Y. (2014). Halal dan haram dalam Islam (penterjemah. Zulkifli Mohamad al- Bakri). Nilai: Pustaka Cahaya Kasturi Sdn. Bhd.

Al-Qattan, H. M., Amlih, D. F., Sirajuddin, F. S., et al. (2019). Quantifying the levels of knowledge, attitude, and practice associated with sickle cell disease and premarital genetic counseling in 350 Saudi adults. Hindawi Advances in Hematology, 9(2), 1-7. 
Alanazi, F., Jones, A. \& Menon. C. (2018). Sharia law and digital forensics in Saudi Arabia. Journal of Digital Forensics, Security and Law, 13(3), 5-20.

Ambali, A.R. \& Bakar, A.N. (2014). People's awareness on halal foods and products: potential issues for policy-makers. Procedia-Sosial and Behavioral Science, 121(2), 3-25.

Aminrad, Z., Zakariya, S. Z. S., Hadi, A. S., et al. (2013). Relationship between awareness, knowledge and attitudes towards environmental education among secondary school students in Malaysia. World Applied Sciences Journal, 22(9), 1326-1333.

Ansari, N.U. \& Mohammed, H. (2015). Factors affecting the intent to purchase halal personal care products: empirical evidence from Pakistan. International Journal Islamic Marketing and Branding, 1(2), 199213.

Arsat, A. S., Bachok, C., Chik, C., T., et al. (2016). Preferences towards quality, trust and trend in halal restaurant. Heritage, Culture and Society, 2(1), 735-738.

Awan, H., Siddiquei, A. N. \& Haider, Z. (2015). Factors affecting halal purchase intention-evidence from Pakistan's halal food Sector. Management Research Review, 3(6), 640-660.

Aziz, Y. A. Z. \& Chok, N. V. (2013). The Role of halal awareness, halal certification, and marketing components in determining halal purchase intention among non- Muslims in Malaysia: a structural equation modeling approach. Journal of International Food \& Agribusiness Marketing, 25(1), 1-23.

Bashir, A. M., Bayat, A., Olutuase. S. O., et al. (2018). Factors affecting consumers' intention towards purchasing halal food in South Africa: a structural equation modelling. Journal of Food Products Marketing, 25(1), 26-48.

Che Hashim, H. I. C. \& Shariff, S. M. M. (2016). Halal supply chain management training: issues and challenges. Procedia Economics and Finance. 37(2016), 33- 38.

Che Man, Y. B. \& Abdul Latif, M. (2002). Halal and cultural aspects of livestock production and marketing. International Livestock Research Institute, 8(2), 215- 220.

Chik, C. T., Abdullah, M. A., Bachok, S., et al. (2018). Halal crisis management in small medium food enterprises. International Journal of Administration and Governance, 4(2), 5-10.

Darlington, D., Anitha, F. \& Joseph, C. (2019). study of knowledge, attitude, and practice of organ donation among medical students in a tertiary care centre in South India. Cureus, 11(6), 1-9.

Department of Standards Malaysia. (2017). Small and Medium Enterprise (SMEs) performance 2017. Cyberjaya: Department of Standards Malaysia.

Elias, E. M., Othman, S. N., Yaacob, N. A., et al. (2016). A study of halal awareness and knowledge among entrepreneur undergraduates. International Journal of Supply Chain Management, 5(3), 2050-7399.

Elseidi, R. (2018). Determinants of halal purchasing intentions: Evidences from UK. Journal of Islamic Marketing, 9(1), 167-190.

Gurcharan, N. N. \& Mohamad, S. (2016). Factors influencing general employee's perception and attitude towards halal logistics adaptation. Science International (Lahore), 28(2), 1841-1848. 
Habte, A., Addisie, A. \& Azazh, A. (2018). Assessment of knowledge, attitude and practice of disaster preparedness among Tikur Anbessa Specialized Hospital health care workers, Addis Ababa, Ethiopia. American Journal of Nursing Science, 7(1), 39-48.

Halal Industry Development Corporation. (2018, May 4). Retrieved from http://www.hdcglobal.com

Hashim, P. \& Mat Hashim, D. (2013). A review of cosmetic and personal care products: halal perspective and detection of ingredient. Pertanika Journal of Science \& Technology, 21 (2), 281-292.

Henley, S. H. A. (1984). Unconscious perception re-revisited: A comment on Merikle's (1982) paper. Bulletin of the Psychonomic Society, 22(1), 121-124.

Ishak, N. H. I. (2017). Concept paper: Customer satisfaction in Malaysian takaful industry. International Journal of Academic Research in Business and Social Sciences, 7(3), 380-391.

Ismail, S., Zainuddin, H., Hamedon, T. R., et al. (2018). Factors associated with awareness, knowledge and attitude towards prostate cancer among Malay men in traditional Malay villages, Negeri Sembilan, Malaysia. Malaysian Journal of Medicine and Health Sciences, 14(2), 31-38.

Jais, A. S. (2014). Halal in mainstream education: where are we now and what the future holds for halal education? International Seminar on Global Education, 2(1), 1179-1191.

Knowledge. (1999). In dictionary.cambridge.org. Retrieved on October 2, 2019, from https://dictionary.cambridge.org/dictionary/english/knowledge

Kusumawardhini, S. S., Hatib, S. R. H. \& Daryantic, S. (2016). Understanding Islamic brand purchase intention: the effects of religiosity, value consciousness, and product involvement. The European Proceeding of Social \& Behavioral Sciences, 158-166.

Lada, S., Geoffrey, H. T. \& Hanudin, A. (2009). Predicting intention to choose halal product using theory of reasoned action. International Journal of Islamic and Middle Eastern Finance and Management, 2(1), 66-76.

Latiff, Z. A. A., Ruslee, N. A. \& Ayob, M. A. (2016). Factors influencing consumer purchasing intention based on food labels. International Business and Management, 13(1), 41-45.

Liu, Y, Li1, J., Zheng, Q., et al. (2016). Knowledge, attitudes, and perceptions of autism spectrum disorder in a stratified sampling of preschool teachers in China. BMC Psychiatry, 2(1), 16-142.

Majid, M. B., Sabir, I. \& Ashraf, T. (2015). Consumer purchase intention towards halal cosmetics and personal care products in Pakistan. Global Journal of Research in Business and Management, 1(1), 47-55.

Maqsood, R. W. (1998). Living Islam. India: Goodword Books.

Marmaya, N., Zakaria, Z. \& Mohd Desa, M. (2019). Gen Y consumers' intention to purchase halal food in Malaysia: a PLS-SEM approach. Journal of Islamic Marketing, 10(3), 1003-1014.

Merikle, P. M. (1984). Toward a Definition of awareness. Bulletin of the Psychonomic Society, 22(5), 449450.

Ministry of Human Resources (MOHR). (2009). Occupational structure halal industry. https://www.dsd.gov.my/jpkv4/images/analisis-bidang-pekerjaan- oa/Halal_Industry_JDI29423.pdf 
MITI (Ministry of International Trade and Industry Report) 2016. (2016). Status of the Halal Industry. Kuala Lumpur. Retrieved from http://www.mihas.com.my/ wp- content/uploads/2016/02/WHW-2016Status-of-the-Halal-Industry.pdf

Mohammed, B. S., Fethi, A. \& Djaoued, O. B. (2017). The influence of attitude, subjective norms and perceived behavior control on entrepreneurial intentions: Case of Algerian students. American Journal of Economics, 7(6), 274-282.

Mohd Azaman, N. N., Kamarulzaman, N. H., Shamsudin, et al. (2016). Stakeholders knowledge, attitude, and practices (KAP) towards Atoxins contamination in peanut-based products. Food Control, 70, 249 256.

Muhammad, N. M. N., Isa. F. M. \& Kifli B. C. (2009). Positioning Malaysia as halal- hub: Integration role of supply chain strategy and halal assurance system. Asian Social Science, 5(7), 44-52.

Nasir, R. \& Lin, L. S. (2013). The Relationship between self-concept and career awareness amongst students. Asian Social Science, 9(1), 1911-2025.

Neni, W. S., Subrain, G., Shamshir Khan, M. S. N. N. et al. (2019). Awareness, knowledge, and attitude (AKA) of government secondary school students on the use of antibiotics in Shah Alam, Malaysia. Journal of Public Health, 3(2), 1-9.

Nuratifah, A. S., Sharifudin, M. S. \& Mariam, A. L. (2019). Evaluation of knowledge and practices of halal certification among food processing companies in Sabah, Malaysia. International Food Research Journal, 26(1), 295-304.

Nwankwo, O. N. O., Mokogwu, N., Agboghoroma, O., et al. (2018). Knowledge, attitudes and beliefs about the health hazards of biomass smoke exposure amongst commercial food vendors in Nigeria. PLoS One, 13(1), 1-8.

Nguyen, T. T. \& Watanabe, T. (2019). Win-win outcomes in waste separation behavior in the rural area: A case study in Vietnam. Journal of Cleaner Production, 230(2), 488-498.

Rafida, A. R. N., Mashitoh, A. S., Alina, A. R., et al (2013). Negotiating interests according to Islamic approach on halal certifications: Challenges in creating jobs. World Applied Sciences Journal, 1116.

Rajagopal, S., Ramanan, S., Visvanathan, R., et al. (2011). Halal certification: Implication for marketers in UAE. Journal of Islamic Marketing, 2(2), 138-153.

Sadeeqa, S., Sarriff, A., Masood, I., et al. (2013). Evaluation of knowledge, attitude, and perception regarding halal pharmaceuticals, among general medical practitioners in Malaysia. Archives of Pharmacy Practice, 4(2), 139-46.

Said, M., Hassan, F., Musa, R., et al. (2014). Assessing consumers' perception, knowledge and religiosity on Malaysia's halal food products. Procedia-Social and Behavioral Sciences, 130(1), 120-128.

Salman, F. \& Siddiqui, K. (2011). An exploratory study for measuring consumers awareness and perceptions towards halal food in Pakistan. Interdisciplinary Journal of Contemporary Research in Business, 3(2), 639-643. 
Samori, Z., Ishak, A. H. \& Kassan, N. H. (2014). Understanding the development of halal food standard: Suggestion for future research. International Journal of Social Science and Humanity, 4(6), 482486.

Shaari, J. A. N. \& Arifin, N. S. B. M. (2010). Dimension of halal purchase intention: A preliminary study. International Review of Business Research Papers, 6(4), 444- 456.

Shahid, I. (2017). Retrieved from https://www.linkedin.com/pulse/importance-Halal-income-islam-islamicfinance-consultant-

Shariff, S. M, Mohamad, S. \& Che Hashim, H. I. (2016). Human capital development in halal logistics: halal professionals or halal competent persons. Journal of Applied Environmental and Biological Sciences, $6(8), 1-9$.

SME Corporation Malaysia. (2016). SME Annual Report 2016/17. Retrieved from http://www.smecorp.gov.my/index.php/en/sme-annual-report-2015

Tawil, N. M., Ramlee, S., Jaafar, J., et al. (2015). An overview of foodpreneur awareness among small and medium-sized enterprises (SME) of halal certification. Asian Social Science, 11(21), 91-94.

Wahab, A. R. (2004). Guidelines for the preparation of halal food and goods for the Muslim consumers. AmalMerge-Halal and Food Safety Institute, 1-12.

Yunus, N. S. M., Yusof, R. N. R. \& Hashim, H. (2018). Predicting Muslim consumers' purchase intention of previously retracted and recertified halal products. Journal of Emerging Economies and Islamic Research, 7(1), 55-64.

Yunus, N. S. N. M., Rashid, W. E. W., Ariffin, N. M., et al. (2014). Muslim's purchase intention towards nonMuslim's halal packaged food manufacturer. Procedia-Social and Behavioral Sciences, 130(1), 145154.

Yusof, A., Chia, Y. C. \& Hasni, Y. M. (2014). Awareness and prevalence of mammography screening and its predictors - a cross sectional study in a primary care clinic in Malaysia. Asian Pacific Journal of Cancer Prevention, 15(19), 8095-8099.

Yusoff, F. A. M., Yusof, R. N. R. \& Hussin, S. R. (2015). Halal food supply chain knowledge and purchase intention. International Journal of Economics and Management, 9(1), 155-172.

Yusoff, S. Z. \& Adzharuddin, N. A. (2017). Factor of awareness in searching and sharing of halal food product among Muslim families in Malaysia. International Conference on Communication and Media: An International Communication Association Regional Conference (i-COME'16), 33(1), 1-7.

Zakaria, Z., Majid. M. D. A., Ahmad, Z., et al. (2017). Influence of halal certification on customers' purchase intention. Journal of Fundamental and Applied Sciences, 9(5), 772-787. 